\title{
Father-Child Relations after Divorce in Four European Countries: Patterns and Determinants
}

\author{
Matthijs Kalmijn
}

\begin{abstract}
Using nationally representative data on secondary school children in England, Germany, the Netherlands, and Sweden, this study describes the relationships that children have with their fathers after divorce. Differences in the post-divorce relationship are explained in terms of demographic factors, socioeconomic factors, and contextual differences (between countries and between immigrants and natives). The focus is on living arrangements after divorce, the amount of contact with the father, and the perceived quality of the relationship. Many children have at least weekly contact with their father but one in six children never see their father at all. Fathers in high-status families are more highly involved in the child's life after divorce than fathers in low-status families. A mother's employment also has a positive effect on the post-divorce relationship with the father. Co-parenting is most common in Sweden. Post-divorce relationships are also strongest in Sweden and relatively weak in Germany. Immigrant children see their fathers less often after divorce than native children. In the second generation, children of mixed marriages in particular tend to have little contact with the father.
\end{abstract}

Keywords: Divorce $\cdot$ Fatherhood $\cdot$ Children $\cdot$ Parent-child relations $\cdot$ Immigrants

\section{Introduction}

One of the more important consequences of divorce is the effect it has on the father-child relationship (Pryor/Rodgers 2001). It is no surprise then that much research has been done on this topic in recent decades. Some studies focus on longterm effects and compare the relationships that adult children have with their father depending on whether or not the parents divorced or separated when the children were young (A/bertini/Garriga 2011; De Graaf/Fokkema 2007). Other studies focus on short-term effects and examine the relationship that divorced fathers have with their children when the children are still living at home, usually with the mother 
(Adamsons/Johnson 2013; Juby et al. 2007; Spruijt/Duindam 2009). In general, the degree to which divorced fathers remain involved in children's lives after divorce is an important issue for understanding the well-being of both children and fathers, is relevant for the resources that fathers can pass on to their children, and has an impact on the degree to which fathers receive support from children when they are old and in need of support (Daatland 2007; Kalmijn 2007; Lin 2008; Seltzer/Bianchi 2013). Because paternal involvement can be affected by legal custody and visiting arrangements and by rules about alimony, it is also of concern to policy makers and health practitioners.

Although there is consensus that a divorce weakens father-child relationships, there is considerable heterogeneity in this effect. Some divorced fathers maintain frequent contact and remain an influential father figure in the child's life; other divorced fathers lose contact or remarry and shift their investments to a new family (Cheadle et al. 2010; Manning/Smock 1999). In understanding these differences, authors have looked at several types of moderating variables. Most authors have focused on life course factors such as the child's age at divorce, repartnering, residential moves, and employment changes (Aquilino 2006; Cooksey/Craig 1998; Jubyet al. 2007). Fewer authors have examined how the social context in which the divorce takes place moderates the impact of divorce. Examples of contexts that may be important are the country in which parents live (Kalmijn 2008), the time period in which the divorce occurs (Albertini/Garriga 2011), and the ethnic or racial group to which the parents belong (Kalmijn 2010; King et al. 2004). These contexts are relevant because they are related to the cultural climate in which a divorce occurs, to the legal and informal rules about how to deal with divorce and single parenthood, and to the economic opportunities that families are facing. Other potentially relevant moderators about which little is known are the socioeconomic characteristics of parents such as their education, occupational status, and employment. There is debate about whether children from high-status families are protected from the adverse consequences of divorce (Bernardi/Radl 2014; Mandemakers/Kalmijn 2014), but it is not known if father-child relationships are more or less affected by a divorce in high-status families.

In this study, new data from 14-year-old children in four European countries are analysed to examine the determinants of the father-child relationship after divorce. The first goal is to describe three aspects of the father-child relationship for adolescents whose parents divorced or separated. The focus is on residential arrangements (where does the child live?), the amount of contact with the father, and the perceived quality of the relationship. While these aspects have been described before, virtually all demographic and sociological studies are based on American or Canadian data. As a result, even the simplest facts such as the percentages of coparenting arrangements after divorce are unknown for most European countries. Moreover, there is much popular debate and concern about divorced fathers who never see their children (e.g. Zander 2012) but we do not have good data on how common this is. There are now several European studies on adult children and their divorced fathers (Albertini/Garriga 2011; Kalmijn 2008), but studies on children who are still living at home are scarce. Because we have nationally representative data, 
this study is able to fill in this important gap in the literature. The second goal is to understand heterogeneity in father-child relationships after divorce. To meet this goal, we develop hypotheses about the influence of three types of characteristics on each aspect of the father-child relationship. More specifically, we focus on demographic characteristics, socioeconomic characteristics, and contextual characteristics (i.e. country differences and differences among immigrants and natives as well as among major immigrant groups). We test hypotheses about the influence of these characteristics in a series of multivariate regression models.

\section{Hypotheses}

\section{Socioeconomic characteristics}

Our first set of hypotheses is about socioeconomic characteristics, in particular the socioeconomic status of the family and the employment status of the mother. There are several reasons why the socioeconomic status of the family may affect postdivorce relationships. First, studies have shown that more highly educated fathers are more involved in child rearing tasks than fathers with lower levels of education (Hook/Wolfe 2012; Sayer et al. 2004; Yeung et al. 2001). The more fathers are involved in their children's lives, the more likely it is that the ties will remain strong after divorce. Fathers may be more attached to their children when they were highly involved, just as children may be more attached to their fathers. In the legal decision-making after divorce, these investments may also be recognized and this may give fathers more opportunity to retain contact or to obtain custody or co-parenting rights. A second argument is that fathers in high-status families may be more effective in working out post-divorce agreements with the mother (Ryan et al. 2008). Thirdly, higher-status fathers and mothers read newspapers and magazines more often (Kraaykamp 2002) and may therefore be more aware of public knowledge about the negative effects of divorce on children. For these reasons, we believe that parents in high-status families will pay more attention to the well-being of the child and this means, among other things, more balanced roles for the father and the mother after divorce. In sum, our hypothesis is that children in high-status families have stronger ties to their fathers than children in lower-status families. This would apply to all three outcomes that we study: co-parenting will be more likely, frequent contact will be more likely, and ties will be of higher quality.

The father-child relationship may also be affected by the employment status of the mother. There is considerable heterogeneity in female employment after divorce, with many divorced mothers who are not working for pay (Van Damme 2010). There is debate about the possible effects of mothers' employment on children's well-being and school outcomes and the potentially mediating role of parent-child relationships in these effects (Waldfogel et al. 2002). Consensus has arisen that mothers' employment does not have general negative effects on child outcomes (Waldfogel et al. 2002). There is also little evidence that maternal employment competes with the time mothers spend with children, although there may be a quality/ 
quantity trade-off among employed mothers (Bianchi 2000). It is not known, however, what influence employment has in single-parent families where working mothers cannot rely on their partner to support them with child rearing tasks. We suspect that for single mothers, employment may have more negative outcomes for children. More specifically, we expect that single mothers who work for pay have less time and energy for their children than single mothers who are at home most of the time. As a result, the children will be more likely to live (permanently or at least part of the time) with the father and will see their father more often as well if the mother works for pay. This will apply in particular to full-time working mothers but no information is present in our data on the mothers' working hours. Moreover, in families where the mother works, the father may already be more involved in child rearing tasks to begin with. Since early investments in a child have positive effects on the relationship with the child when the marriage breaks down (Juby et al. 2005), the effect of maternal employment could work in both ways: via the time that mothers have and via the investments that fathers make.

\section{Demographic characteristics}

The literature has shown that there are no clear gender differences in the consequences of divorce for children's well-being except for a somewhat stronger effect of divorce on the problem behaviour of boys than on the problem behaviour of girls (Amato 2001). In addition, past studies find inconsistent effects of gender on post-divorce contact (Cooney 1994; Swiss/Le Bourdais 2009; Manning et al. 2003; Cooksey/Craig 1998). Theoretically, one would expect that divorced fathers have stronger ties to sons than to daughters: Attachment is believed to be stronger to the same-sex parent, the development of a child's gender identity is more difficult when a child is raised by an opposite-sex parent, and a parent may feel more comfortable in advising a same-sex child than an opposite-sex child (Powel//Downey 1997). It is important to realise that this influence may be bi-directional: fathers may feel a stronger attachment to their son than to their daughter and hence take more initiative for contact, but sons may also feel a stronger attachment to their father than daughters and consequently visit more often. It is difficult to unravel these processes but we can develop some additional tests to clarify these things. If the effect of child gender on contact disappears when controlling for the quality of the tie with the father as perceived by the child, the gender difference probably stems from differences in what the children - sons and daughters - want. If the effect of child gender on contact remains when controlling for the perceived quality of the tie with the father, the gender difference also has to do with the preferences of fathers for sons as opposed to daughters.

The second demographic variable is the number of siblings. Research on adult intergenerational relationships has found that adult children have contact with their parents less often when they have more siblings (Grundy/Read 2012). From the perspective of parents, there is a benefit in having a large family: parents with many children have more contact with at least one of the children. At the dyad level, however, the effect of sibsize on contact frequency is negative. This can be interpreted 
in terms of time constraints (when there are more children, parents have less time per child) and in terms of a "division of labour" within families (when one child visits often, the other child may not need to visit). In this study, we examine if such an effect also exists for children of divorced parents who live with their mother, something that has not been studied as far as we know. For this more specific case, it is not clear if the effect will operate. Young children who live with the mother may see their father simultaneously. This reduces the role of time constraints and may result in an insignificant "sibsize" effect on father-child contact. There may be a negative effect of sibsize on co-parenting if fathers find it more difficult to care for a large family than for a small family

Whether or not the mother repartners is another important demographic variable in the literature on divorce. In the present study, we have good information on whether the mother has a new partner but we only know this if the child lives with the mother. Previous research has not found consistent effects of the mother's repartnering. A cross-sectional study finds a negative effect of the mother's remarriage on visitation frequency with the father (Stephens 1996). A recent longitudinal study, however, shows that the entry of a stepfather in the mother's household does not lead to less frequent contact or a poorer quality relationship with the (biological) non-resident father (King 2009). This refutes the hypothesis that stepfathers are substitute parents. We test this notion again, this time using large-scale albeit crosssectional data in four European countries. Unfortunately, we do not have data on whether the father is remarried when the child is not living with him.

\section{The national context: Origin and destination effects}

There are two ways that the national context may play a role. First, there can be differences between destination countries, i.e. between England, Germany, the Netherlands, and Sweden. Second, there can be differences based on origin countries. Because schools with high numbers of immigrants were systematically oversampled, we can examine differences between natives and (first- and second-generation) immigrants, as well as between immigrant groups themselves. This allows us to examine "origin country" effects.

Starting with the destination effects, the question is: can we expect differences in post-divorce father-child relationships among the four countries? One hypothesis suggests that in countries with higher rates of divorce, there will be more frequent contact between the child and the divorced father. Divorce is more institutionalised in these countries and legal arrangements are more favourable for divorced fathers (Albertini/Garriga 2011; Kalmijn 2008). How do divorce rates vary among the four countries? To assess this, we present net divorce rates for 2002 and 2011 in Figure 1. Net divorce rates are not widely available and were constructed as the annual number of divorces divided by the population of married women in a year (in 1000s), based on data from the United Nations Statistics Division or the country-specific statistical websites (Office for National Statistics, Statistisches Bundesamt, CBS Statline). For England and Wales, the early divorce rate is for 2001, the year in which the census was taken. The figure shows that divorce is most common in Sweden 
Fig. 1: Net divorce rates by country

Divorces per 1,000 married women

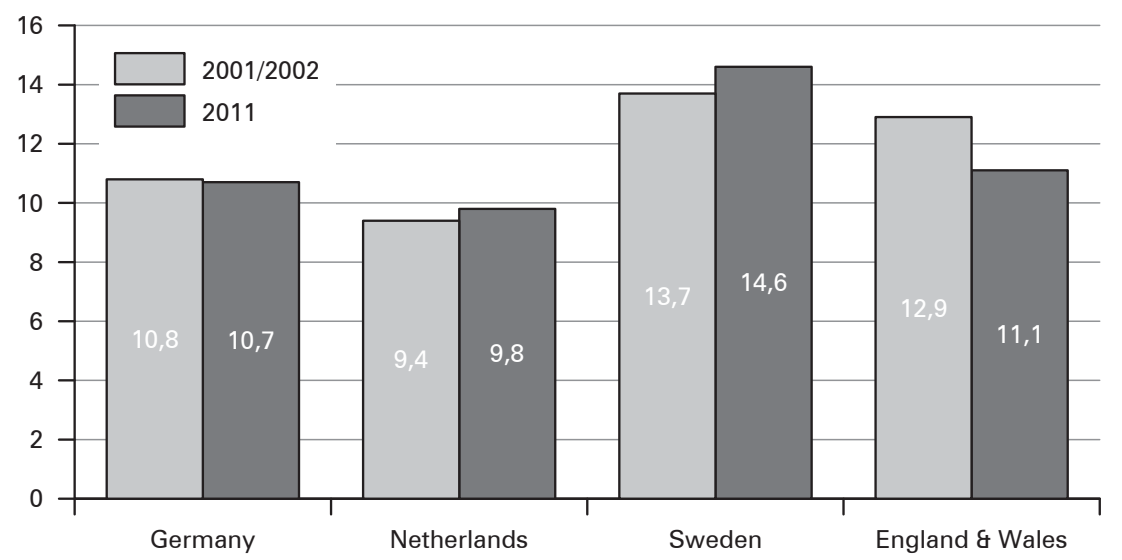

Note: For England and Wales data refer to 2001; other countries refer to 2002.

Source: United Nations Statistics Division, Office for National Statistics (UK), Statistisches Bundesamt (Germany), CBS Statline (Netherlands)

and England and less common in Germany and the Netherlands. In England, the net divorce rate declined between 2001 and 2011 so that it is now more similar to that in Germany and the Netherlands. Our data were collected in 2010-2011 but the parents may have divorced at an earlier point in time. Hence, to compare divorce rates, we need to look at the entire decade. Based on this line of reasoning, we would expect to find the strongest relationships between fathers and children in Sweden and England, and weaker ties in Germany and the Netherlands.

The four destination countries also differ in their gender roles. Attitudes toward maternal employment are more positive in Sweden and the Netherlands than in England and Germany (Kalmijn 2003). The percentage of mothers with young children (under 6) who are employed is also higher in Sweden (76.8) and the Netherlands (77.1) than in Germany (59.7) and the UK (59.1) (OECD website, http://ec.europa. eu/eurostat/data/database, data for 2012). When looking at the division of paid and unpaid work, Sweden stands out as being the most egalitarian (Knudsen/Waerness 2008; Gauthier/DeGusti 2012). Studies of the time fathers spend on childcare show that fathers are more involved in childcare in Sweden than in Germany and England (Gauthier/DeGusti 2012). In sum, when gender roles are the dominant explanation, we would expect Sweden to have the most involved fathers after divorce and Germany and England to have the least involved fathers. The position of the Netherlands will be somewhere in between but is less certain since comparative time diary studies rarely include the Netherlands. Theories about gender roles and the institutionalisation of divorce thus imply a different order of destination countries with respect to father involvement. The comparison between the two high-divorce countries Sweden and England is especially informative in this respect. If gender roles are the dominant mechanism, Sweden will have the most positive post-di- 
vorce father-child relationships, whereas if the institutionalisation effect is dominant, Sweden and England will be similar in this respect.

We now discuss possible differences between immigrants and natives and between the various immigrant groups that make up the European context. Like most other European analyses, we focus on non-western immigrants even though western immigrants are potentially interesting as well. So far, very few studies have analysed post-divorce father-child relationships for immigrants or for ethnic minority groups. Some studies in the US find that black and Hispanic fathers are less involved in their children's lives after divorce than comparable white fathers (Cheadle et al. 2010). Other studies do not find clear differences between major racial groups (Cooksey/Craig 1998; King et al. 2004; Manning/Smock 1999). There are more studies on ethnic and racial differences in child rearing practices but these focus only on intact families (Pe/s/Nijsten 2003; Yaman et al. 2010; Emmen et al. 2013). Why would we expect differences between immigrants and natives in the strength of the father-child relationship after divorce? First, we can look at gender roles in various immigrant groups. In Muslim countries, there is considerably less support for gender equality than in Western countries (Norris/Inglehart 2002). In Latin American and Southern European countries, gender role attitudes are also more traditional but they deviate less from the Western European pattern than Muslim countries (Kalmijn 2003; Norris/Inglehart 2002). As a result, most immigrant fathers could be less involved in child rearing during marriage and if this is true, they consequently may have weaker ties to their children when they are divorced and the children are adolescents.

Secondly, we can consider the institutionalisation hypothesis. In some of the origin countries - especially Muslim countries - divorce and single parenthood are strongly disapproved of (Norris/Inglehart 2002). One would expect that a normal continuation of the father-child relationship after divorce is more difficult when the community disapproves of divorce. In these cases, it is more likely that a divorce coincides with an abrupt discontinuation of contact between the two ex-partners and their respective families. Not all immigrant groups disapprove of divorce and single parenthood, however. Immigrants with African and Caribbean origins in particular are characterised by high levels of single parenthood and high tolerance of divorce (Kalmijn 2010). At the same time, however, it has been argued that in these groups, the role of the father in the family tends to be weaker while networks of female friends and kin are more strongly relied upon to provide support in single-mother families (Sarkisian/Gerstel 2004; Stack 1974). As a result of their more matrifocal orientation, we would expect that the children of African and Caribbean origins will also have a weak relationship to the father after divorce, although for a different reason than is assumed to be true for immigrants from Muslim countries.

Thirdly, economic considerations may play a role. Immigrants from non-western origin countries on average have a weaker economic position in society. Their earnings tend to be lower, they have less education on average, and they are unemployed more often, even when controlling for the influence of education (Heath et al. 2008; Van Tubergen 2004). The weak economic position of immigrant men not only reduces their chances of marrying and increases their chances for divorce 
(Edin/Kefalas 2005; Lichter et al. 1992; Oppenheimer 2003); it may also weaken the position of the father in the post-divorce family. When fathers have few economic resources, they will be less likely to pay child support and this may limit the degree to which they remain involved in the child's life (Arditti/Keith 1993; Hofferth et al. 2010). Economically disadvantaged fathers are also less able to provide a stable and comfortable place for their children to live, which would reduce the options for coparenting. It is therefore important to estimate the effect of immigrant background while controlling for the family's socioeconomic status. While we have multiple indicators of socioeconomic status in our data, we do not have data on the income situation of the absent father. As a result, the net effects of immigrant background should not entirely be interpreted from a cultural perspective; residual economic causes for the differences between natives and immigrants may still play a role.

\section{$3 \quad$ Data and method}

The CILS4EU data were collected in four countries. About 100 secondary schools were randomly chosen per country and two (randomly chosen) classes in each school were used (Kalter et al. 2012). The focus was on year 10 pupils in England, year 9 in Germany, year 3 of secondary schools in the Netherlands, and year 8 in Sweden. The children were about 14 years old in each country. Schools with high proportions of immigrants were systematically oversampled via a stratified sampling scheme to ensure a large enough sample of immigrants. Based on the percentage of immigrants in a school, four strata were constructed and random samples of schools were drawn within these strata. To solve the problem that schools may not be willing to participate, a replacement strategy was used where each school was matched to a replacement school that would be approached if the initial school did not respond. This is similar to the procedures used by other international school studies such as PISA and TIMMS. After replacement, response at the school level was 65.6 percent in England, 98.6 percent in Germany, 91.7 percent in the Netherlands, and 76.8 percent in Sweden (where no replacement procedure was used).

From the original data, we selected children whose parents were divorced or separated. Parents who never lived together were not included. When children had divorced parents, they were first asked about their primary home, i.e., the home where they live most of the time. Next, they were asked about living in another home. It was assessed how often the child lived in this secondary home and with whom. We generated a variable indicating whether the child lives with the father and a variable whether the child lives with the mother. Living with a parent is defined as living with that parent in the primary household or living with that parent in a secondary household for at least half of the time. Cross-classifying these variables yields four categories: living primarily with the mother, living primarily with the father, living with both in two different households, and living with neither parent. In this definition, co-parenting means living with each of the two parents for half of the time. There are children who stay over once a week with the father but we do 
not regard this as co-parenting even if the children regard this as their secondary household. This will be captured in the contact measure, however.

Living arrangements were analysed with a multinomial logit model where the baseline category is living primarily with the mother. Secondly, we defined contact as the frequency of face-to-face contact with the biological father. This was recoded to missing for children who primarily live with their father (in which case there is no variation in contact). Categories were: every day, once or a couple of times per week, once or a couple of times per month, less often, and never. The variable was analysed with an ordinal logit model. Thirdly, we used a question about how well the respondent gets along with the father. The respondent could choose among the following options: very well, well, not so well, and not well at all. This variable was also analysed with an ordinal logit model. The question about quality was not asked if there had never been any contact with the father.

The following socioeconomic variables were used as independent variables: (a) a variable indicating whether the mother works for pay, (b) the family status, which is composed of four variables: father's educational level (coded from 0 for no education to 3 for tertiary), mother's educational level (also coded from 0 to 3 ), father's occupational status, and mother's occupational status. Education was asked via three separate questions, one for each level (primary, secondary, tertiary). It was assumed that if a student answers "don't know" to a level, the parent did not complete that level. A student who answers "don't know" to all three questions or does not answer for other reasons to any question is assigned to missing. The correlation between the father's and mother's education, thus measured, was 0.53 , which gives us confidence in the operational definition. If a mother does not work and the child does not list mother's past occupation, we impute the country-specific mean. Note that a dummy for employment status is included and most missings are due to non-working mothers. Occupations were coded in ISCO-08 (International SocioEconomic Index of Occupations) and recoded to ISEI status scores (Ganzeboom et al. 1992). To create a family status scale, each of the individual status variables was standardised and the mean of the four variables was taken. The scale we constructed is the average of the valid items. We worked with an index in order to use as much information as possible and to reduce the number of missing cases in the regression model. Not all children know the socioeconomic characteristics of their parents. Missings were 6.9 percent for mother's education, 15.3 percent for father's education, 6.2 percent for mother's occupation (for working mothers), and 22.6 percent for father's occupation. An alternative would be to use multiple imputation while using individual status components in the models. This is not preferred because we have no specific hypotheses about which component of status is the most influential.

The following demographic variables were used: (a) the age of the child, (b) the sex of the child, (c) the number of siblings in the (primary) household, (d) whether (or not) the mother is living with a new partner. The repartnering variable was included in a separate model where children who primarily live with the father and children who live with neither parent are excluded. In these cases, no information on repartnering is available. 
Tab. 1: $\quad$ Descriptives of variables used in the analyses $(N=4524)$

\begin{tabular}{lcccc}
\hline & Mean & Standard deviation & Min & Max \\
\hline Mother employed & 0.77 & 0.42 & 0 & 1 \\
Family status index & 0.00 & 1.00 & -3.65 & 2.73 \\
Daughter versus son & 0.52 & 0.50 & 0 & 1 \\
Age of child & 14.48 & 0.67 & 13 & 18 \\
Number of siblings & 1.29 & 1.21 & 0 & 9 \\
Mother new partner & 0.31 & 0.46 & 0 & 1 \\
Germany (vs England) & 0.26 & 0.44 & 0 & 1 \\
Sweden (vs England) & 0.28 & 0.45 & 0 & 1 \\
Netherlands (vs England) & 0.22 & 0.41 & 0 & 1 \\
Immigrant child (1st generation) & 0.08 & 0.28 & 0 & 1 \\
Immigrant child (2nd generation) & 0.24 & 0.43 & 0 & 1 \\
Both parents foreign & 0.13 & 0.33 & 0 & 1 \\
Only father foreign & 0.08 & 0.27 & 0 & 1 \\
Only mother foreign & 0.04 & 0.19 & 0 & 1 \\
\hline
\end{tabular}

Source: Own calculations based on CILS4EU, 2010/2011

The following contextual variables are used. First, we include variables for the country of destination. Second, we consider a variable that makes a distinction between "native" children (i.e. native-born children of two native-born parents) and "immigrant" children (i.e. the native-born children of immigrants and foreign-born children who came to the destination before or during the school ages). We make an additional distinction between $1^{\text {st }}$ and $2^{\text {nd }}$ generation children and we pay special attention to children of mixed parentage: children who have one native-born parent and one foreign-born parent. Finally, we consider immigrant groups, defined on the basis of the country of birth of the mother. If the mother was native-born, the country of birth of the father was used. We distinguish seven regions, following often used classifications of world regions: Southern Europe, Eastern Europe, the larger Middle East (including Northern Africa), Asia, Sub-Saharan Africa, Latin America, and the Caribbean. The means and standard deviations of the independent variables are presented in Table 1.

\section{$4 \quad$ Findings}

Before presenting the regression results, it is interesting to see how often children of divorced parents live with the mother, the father, or both. In Table 2, we present these statistics separately for each of the four countries. The percentages are weighted to correct for the oversampling of schools with high numbers of immigrant 
children. Co-parenting is most common in Sweden: about 36 percent of Swedish children have a co-parenting arrangement. In the Netherlands, 18 percent of the children live in two parental homes. This corresponds well with an earlier study for the Netherlands where it was found that 17 percent of 10-16 year-olds lived in a coparenting arrangement after divorce (Spruijt/Duindam 2009). Co-parenting is least common in England and Germany (about 10 percent). In all countries, however, the majority of children live primarily with their mother. A small minority of children live primarily with the father and even fewer children live without a parent.

For children who do not primarily live with their father, we examined how often they have been in contact with their father (Table 2). Overall, about 40 percent of the children have at least weekly contact with their father, which is a substantial number. There is much heterogeneity, however. About one in six (18 percent) respondents say they never see their father. This is a substantial minority. The no-contact category is smallest in Sweden, larger in the Netherlands, and largest in England and Germany where about one in five children never have contact with the father.

Tab. 2: Descriptive analyses of father-child ties after divorce in four countries

\begin{tabular}{lrrrrrr}
\hline \multicolumn{1}{l}{ England } & Germany & Netherlands & Sweden & Total & N \\
\hline Living arrangement & & & & & & \\
With mother & 74.3 & 70.5 & 70.6 & 51.6 & 70.7 & 3,091 \\
Co-parenting & 10.9 & 9.8 & 17.6 & 36.0 & 12.8 & 786 \\
With father & 9.5 & 12.9 & 6.4 & 7.6 & 10.6 & 389 \\
With neither & 5.3 & 6.8 & 5.4 & 4.8 & 6.0 & 271 \\
Total & 100.0 & 100.0 & 100.0 & 100.0 & 100.0 & 4,537 \\
Contact with father (face-to-face) & & & & & \\
Never (1) & 18.9 & 20.7 & 14.2 & 8.0 & 18.4 & 678 \\
Less often (2) & 17.7 & 16.5 & 8.7 & 15.8 & 16.2 & 717 \\
Monthly (3) & 20.9 & 27.8 & 32.4 & 21.6 & 25.1 & 941 \\
Weekly (4) & 34.4 & 26.4 & 39.2 & 39.3 & 31.8 & 1,376 \\
Daily (5) & 8.1 & 8.6 & 5.5 & 15.2 & 8.6 & 415 \\
Total & 100.0 & 100.0 & 100.0 & 100.0 & 100.0 & 4,127 \\
Perceived quality & & & & & & \\
Gets along: & & & & & & \\
Not well at all (1) & 3.3 & 2.2 & 3.0 & 3.0 & 2.8 & 128 \\
Not so well (2) & 11.8 & 12.1 & 11.8 & 9.5 & 11.8 & 432 \\
Well (3) & 38.6 & 34.0 & 43.9 & 40.5 & 37.3 & 1,484 \\
Very well (4) & 46.3 & 51.6 & 41.3 & 47.1 & 48.2 & 1,753 \\
Total & 100.0 & 100.0 & 100.0 & 100.0 & 100.0 & 3,797 \\
\hline
\end{tabular}

Note: Values refer to coding in ordinal logit models.

Source: Own calculations based on CILS4EU, 2010/2011 
Whether the relationships in these cases are hostile, estranged, or simply neutral and non-existent is not known, nor do we know how these children feel about the father that they never see. Note that the percentage of 18 is based on children who do not live with their father. When we consider all children of divorced parents, 16 percent never see their father.

The large majority of children of divorced parents say they have a good or very good relationship with their father (Table 2). However, a significant minority - about 15 percent in each country - does not have a good relationship with the father (based on children who have contact). It is also of some interest to examine the association between contact and quality. Table 3 shows that there is a positive association, as one would expect. The correlation between contact and quality (when coded "as is") is +.33 , which is reasonable but not very strong. When we look at the table in detail, we see that there is a significant group of children with a mismatch between quality and contact. Of children who qualify the relationship as very good, 9 percent see their father less than once a month. Of children who qualify the relationship as good, 19 percent see their father less than once a month. These numbers point to a possible source of deprivation in children's post-divorce lives.

Tab. 3: The association between contact with the father and perceived quality: Column percentages

\begin{tabular}{lccccr}
\hline \multirow{2}{*}{$\begin{array}{l}\text { Contact } \\
\text { (face-to-face) }\end{array}$} & Very well & Well & Not well & Not well at all & Total \\
\hline Daily & 459 & 240 & 46 & 6 & 751 \\
& 26.2 & 16.2 & 10.7 & 4.7 & 19.8 \\
Weekly & 742 & 549 & 95 & 12 & 1,398 \\
& 42.4 & 37.0 & 22.0 & 9.5 & 36.9 \\
Monthly & 401 & 416 & 105 & 17 & 939 \\
& 22.9 & 28.1 & 24.3 & 13.4 & 24.8 \\
Less often & 149 & 277 & 186 & 92 & 704 \\
& 8.5 & 18.7 & 43.1 & 72.4 & 18.6 \\
Total & 1,751 & 1,482 & 432 & 127 & 3,792 \\
& 100 & 100 & 100 & 100 & 100 \\
\hline
\end{tabular}

Note: Weighted numbers. If there has never been any contact, no question was asked about quality.

Source: Own calculations based on CILS4EU, 2010/2011 


\section{Determinants of living arrangements}

We now turn to an analysis of the determinants of living arrangements. In Table 4, we present the estimates of the multinomial regression model. Living primarily with the mother serves as the comparison group. In all regression models, the standard errors are corrected for the clustering of students in schools. Moreover, all models contain controls for the sample stratum but these effects are not presented in the tables.

The socioeconomic variables have significant effects on living arrangements after divorce. In line with expectations, we find that children from high-status families are more likely to have a co-parenting arrangement. There is no effect of socioeconomic status on living primarily with the father. In addition we find that children are more likely to have a co-parenting arrangement when the mother works for pay. This too is in line with our hypothesis. And again, we find that the effect of employment on living primarily with the father is not as expected; the effect is negative rather than positive. In sum, the socioeconomic effects are as expected for co-parenting but they are not as expected for living primarily with the father. Perhaps the tendency to not live with the mother - which is a small minority - is dependent on more specific circumstances such as the mother's health or personality.

We now discuss the demographic effects on living arrangements. Gender and age differences are substantial. Daughters are less likely to live in a co-parenting

Tab. 4: Multinomial regression of living arrangements after divorce

\begin{tabular}{lcccccc}
\hline & \multicolumn{2}{c}{ Co-parenting } & \multicolumn{2}{c}{ With father } & \multicolumn{2}{c}{ Without parents } \\
& $\mathrm{b}$ & $\mathrm{p}$ & $\mathrm{b}$ & $\mathrm{p}$ & $\mathrm{b}$ & $\mathrm{p}$ \\
\hline Mother employed & $.431^{*}$ & $(.00)$ & $-.820^{*}$ & $(.00)$ & -.222 & $(.15)$ \\
Family socioeconomic status & $.304^{*}$ & $(.00)$ & -.014 & $(.82)$ & .053 & $(.43)$ \\
Daughter versus son & $-.270^{*}$ & $(.00)$ & $-.383^{*}$ & $(.00)$ & $-.294^{*}$ & $(.02)$ \\
Age of child & $-.297^{*}$ & $(.00)$ & $.220^{*}$ & $(.01)$ & .118 & $(.28)$ \\
Number of siblings & .033 & $(.37)$ & -.047 & $(.36)$ & $-.254^{*}$ & $(.00)$ \\
Germany (vs England) & .125 & $(.47)$ & .276 & $(.13)$ & $-.569^{*}$ & $(.01)$ \\
Sweden (vs England) & $1.472^{*}$ & $(.00)$ & $.378^{*}$ & $(.04)$ & -.086 & $(.65)$ \\
Netherlands (vs England) & $.530^{*}$ & $(.00)$ & -.191 & $(.34)$ & .223 & $(.21)$ \\
Immigrant (1st generation) & $-2.386^{*}$ & $(.00)$ & $-.335 \sim$ & $(.09)$ & .300 & $(.13)$ \\
Immigrant (2nd generation) & $-.867^{*}$ & $(.00)$ & -.157 & $(.25)$ & $.319^{*}$ & $(.04)$ \\
Constant & -.041 & $(.74)$ & .042 & $(.81)$ & -.137 & $(.54)$ \\
$\mathrm{N}$ & 4,524 & & & & & \\
Model Chi2 & $678.7^{*}$ & & & & & \\
\hline
\end{tabular}

Note: $p$-values in parentheses. Reference is living primarily with mother. See text for definition of co-parenting.

$$
\sim p<0.10,{ }^{*} p<0.05
$$

Source: Own calculations based on CILS4EU, 2010/2011 
arrangement and this applies even more to living primarily with the father. These effects are in line with expectations. Older children are less likely to live in a coparenting arrangement. We find no effects of the number of siblings except on living without parents, which is less common in large families. Presumably, arranging such a situation may be more complicated when there are many children.

Contextual differences are substantial as well. Co-parenting is most common in Sweden and more common in the Netherlands than in England and Germany. Living primarily with the father is more common in Sweden as well. There are also differences between natives and immigrants. Children of immigrants are much less likely to live with their father after divorce. This applies most strongly to coparenting. A clear generational difference is found as well, with second-generation children being more likely to have a co-parenting arrangement than first-generation immigrants. The contrast between the generations for co-parenting is significant $\left(X^{2}=13.9, p<.01\right)$. This is consistent with standard notions from assimilation theory since co-parenting is a recently developed arrangement in western societies to which immigrant groups may adapt as they become more integrated in the host society. Finally, second-generation immigrants are more likely to live with neither parent after divorce. The more important role of the extended family (e.g. grandparents) in immigrant groups may play a role here. Since living with neither parent is often associated with poverty (Hynes/Dunifon 2007) and with poorer child wellbeing compared to other non-standard families (Sun 2003), this effect may be an important disadvantage that immigrant children face while growing up.

\section{Determinants of contact and quality}

The models for contact and quality are presented in Table 5 and 6 respectively. The models for contact exclude children who primarily live with their father. In these cases, contact is probably daily and does not vary. To examine if the determinants affect contact primarily through co-parenting, we also estimated the model again while excluding children with co-parenting. In this model, the outcome is contact with a non-residential father. The approach is the same for quality in Table 6, except that children who never have contact with the father were not asked about the quality of the tie so these are missing.

We first see that children from high-status families have more frequent contact with their divorced father and perceive the quality of the tie to be better. These findings are in line with our expectations. The quality of the relationship with the father is also better in high-status families that divorce. Contact is more strongly affected by status than quality. We also find that when the mother works, the child sees the father more often and the quality of the tie with the father is better. This last effect is not as expected but may be a product of more frequent contact with the father when the mother works: more contact may improve the relationship. Both effects on contact - of socioeconomic status and mother's employment - are still significant when we limit the sample to children who primarily live with the mother (Model 5). Hence, the effects are not solely a product of more frequent co-parenting in high-status families. 
Sons are more likely to have contact with their divorced father than daughters and they also perceive the quality of the relationship to be better. What happens when we control the effect of child gender on contact for the effects of the quality of the relationship with the father and the mother? In a linear regression model for the contact scale, the gender effect is $b=-.24$ without controls and $b=-.07$ with controls $(p=.02)$. In other words, a large part of the gender difference in contact has to do with differences in the way sons and daughters assess the relationship with the father. However, even for children who assess the quality of the relationship with the father as similar, sons more often see their father than daughters. This suggests that the gender difference is in part also due to the preferences and behaviours of the father, but the children's own role seems to be the more important one.

The other demographic variables have mixed effects. There is no effect of the number of siblings. Older children are less likely to see their father than younger children and more likely to assess the quality as poor. The most interesting finding is the effect of repartnering. When the mother lives with a new partner, children have less frequent contact with their divorced father than when the mother lives without a partner. The quality of the relationship with the father is not affected, however. This provides mixed evidence for the notion that stepfathers are substitutes. In terms of contact this may be true, but not in terms of what the father means to the child. The negative effect of the stepfather on contact with the biological father is the same when we limit the sample to children who primarily live with their mother (Model 5).

Are there contextual differences in contact and quality? Table 5 suggests that contact with the divorced father is most frequent in Sweden, least frequent in Germany, with England and the Netherlands in between. These differences are partly due to differences in living arrangements. When we focus on children who primarily live with their mother (Model 5), Sweden no longer stands out. In this model, Germany stands out as a country where divorced fathers have the least frequent contact with their children. Note that there are no differences in the quality of the father-child relationship among the countries.

Are there differences in father-child relationships between immigrants and natives, between immigrant generations, and between immigrant groups? In Model 1, we first see that immigrant children are less likely to have frequent contact with their divorced father than natives. The effect is especially pronounced for the first generation. This raises the question of whether the gap we find is a phenomenon that is limited to the first generation. When looking at the effect for the second generation, this appears not to be true. The effect is $b=-.31$ which shows that second-generation children have a 27 percent lower odds to have frequent (e.g. at least weekly) rather than less frequent (e.g. less than weekly) contact compared to native-born children of native parents. ${ }^{1}$ Similar effects are found for the quality of the relationship. First and second-generation immigrant children evaluate the relationship with their divorced father more negatively than native born children of native origins.

1 Formally, this means that the odds of being in contact category $\mathrm{j}>\mathrm{k}$ rather than in contact category $\mathrm{j} \leq \mathrm{k}$ are 27 percent lower for second-generation immigrants. 


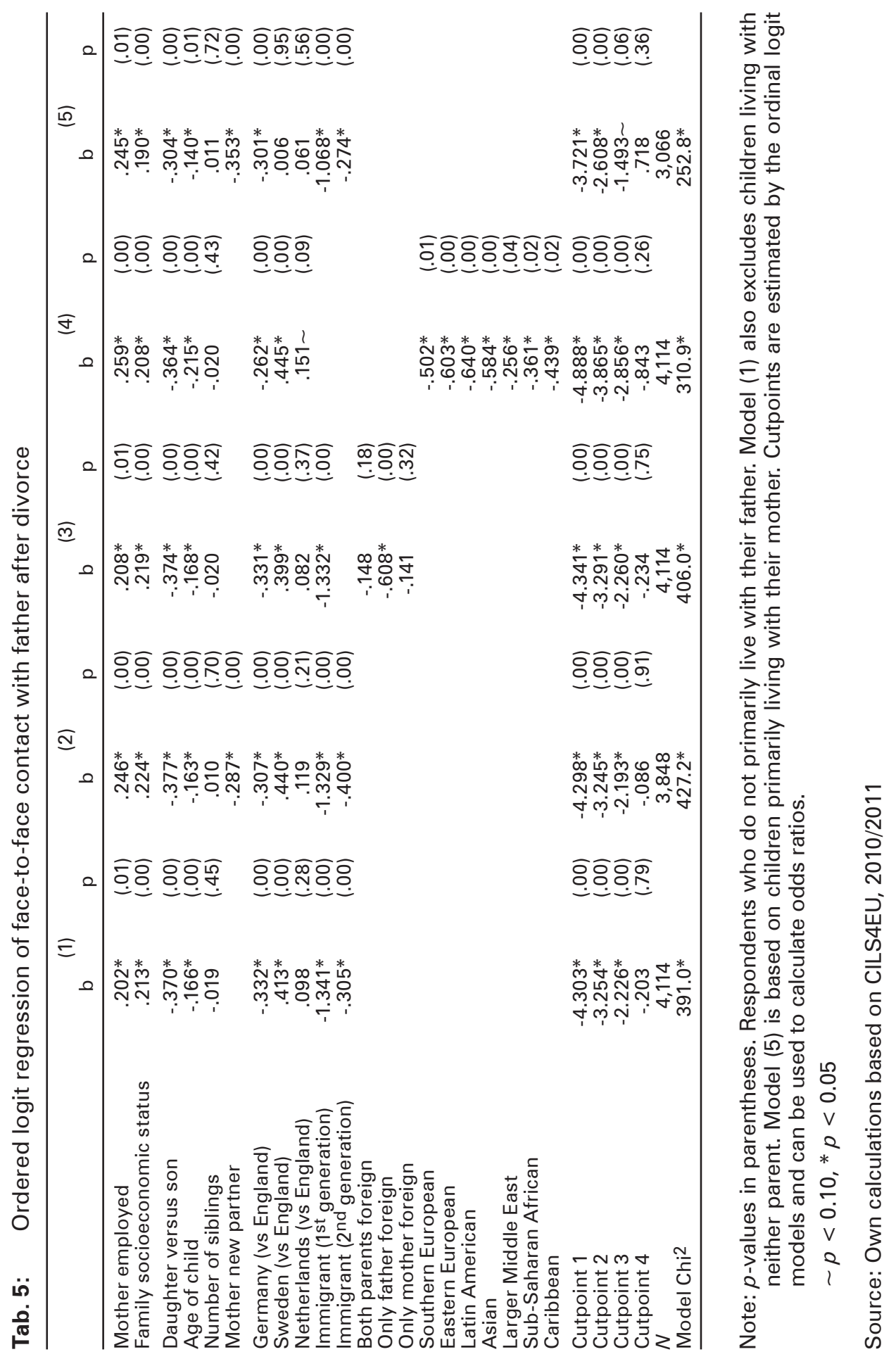


Father-Child Relations after Divorce in Four European Countries

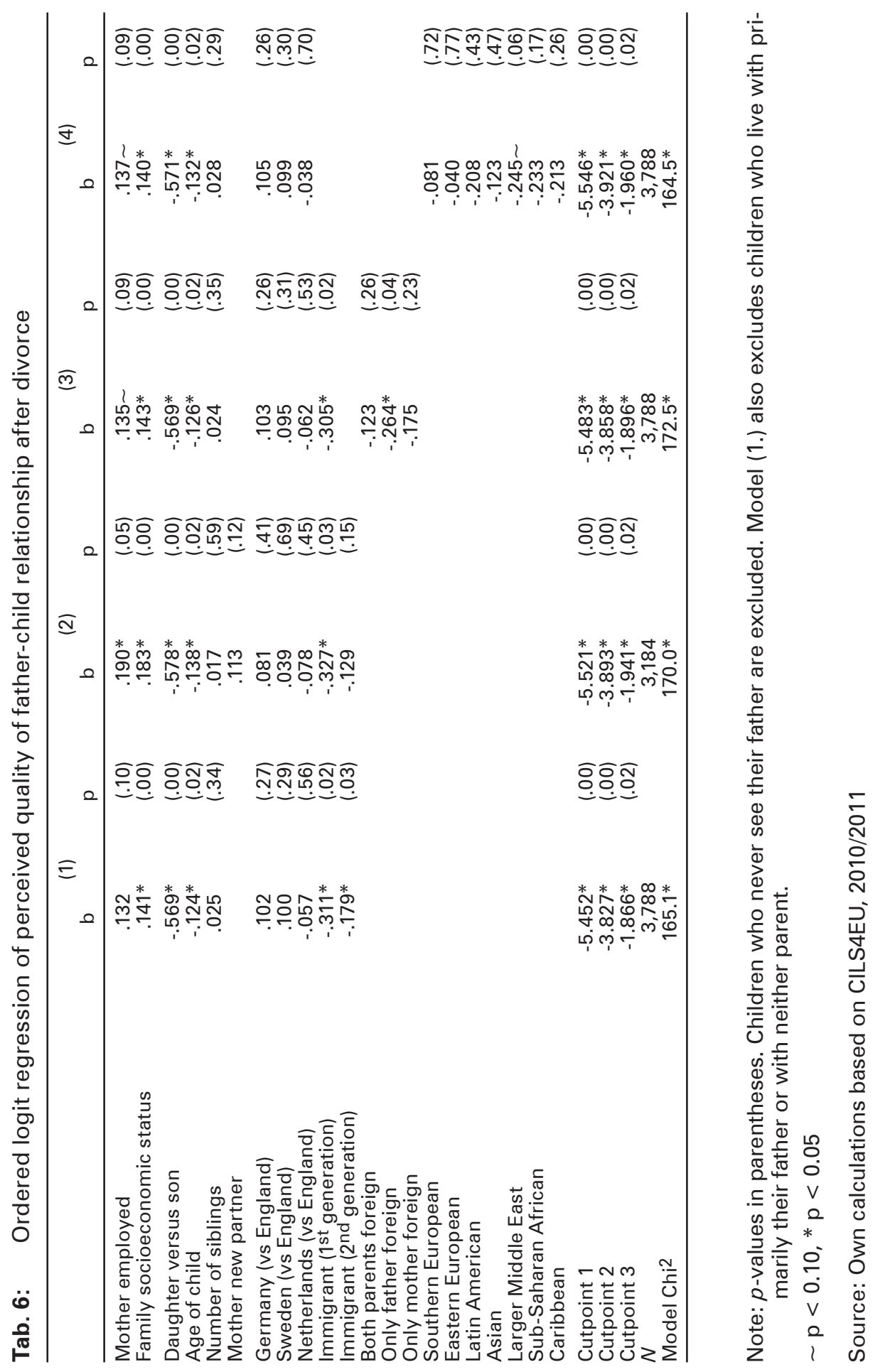


Does it matter which parent is foreign-born? In Model 3, we make a distinction between three types of (second-generation) children: (a) both parents born abroad ( $n=579)$, (b) only the father foreign-born $(n=347)$, and (c) only the mother foreignborn $(n=175)$. Categories (b) and (c) are the children of an ethnically mixed marriage. When only the mother is foreign-born, there is no difference with natives. When both parents are foreign-born, the contrast with natives is significant but small. It is primarily when the father is foreign-born and the mother is native-born that we find less frequent post-divorce contact compared to natives. In other words, children in mixed marriages where the father is foreign-born tend to lose contact with the father more frequently. For quality, we see the exact same pattern of results: children from mixed marriages have poorer ties to their divorced father but this is only true when the father is foreign and the mother is native. Remember, however, that first-generation immigrants are also less likely to have frequent contact and evaluate the relationships with their divorced father more negatively. In other words, there is an effect of intermarriage but also an effect of immigrant status.

To what extent are there differences among the various immigrant groups? To examine this, we distinguish broad regions in Model 4. We first conduct an extra test where the effects for all regions are the same. This hypothesis cannot be rejected $\left(X^{2}=5.5, p=.48\right)$. Hence, the difference between natives and immigrants does not depend on the subgroup we look at. The individual effects vary from - .36 for Sub-Saharan African immigrants to -.64 for Latin American immigrants. These are not small differences but apparently not large enough to be significant with the present sample size. For quality, we find the same pattern but the group-specific effects are smaller and often not significant. ${ }^{2}$ The test for equal effects across groups cannot be rejected $\left(X^{2}=2.1, p=.91\right)$. Hence, there is more evidence for a general immigrant background effect than for a group-specific effect.

\section{Country differences in effects?}

So far, we pooled the four countries and included a main effect. This assumes that the effects of the other variables are similar across settings. In the last part of the analyses, we examine this assumption by presenting models for each country separately. We build one new model that summarises the main patterns. More specifically, we include all respondents regardless of living arrangement and look at the frequency of contact. This model takes into account that contact can be frequent because of a favourable living arrangement and therefore it combines the results for living arrangements and contact frequency. Table 7 presents the country-specific estimates. We abstain from testing the differences across countries and simply describe the patterns that we see, focusing on whether or not an effect is significant. The effects of the family's socioeconomic status exist in all countries but the effect of a mother's employment is present only in England and Germany. Gender differ-

2 The general immigrant effect is significant for quality but the region-specific effects "distribute" this effect among many dummy variables, which on their own are often not significant. 


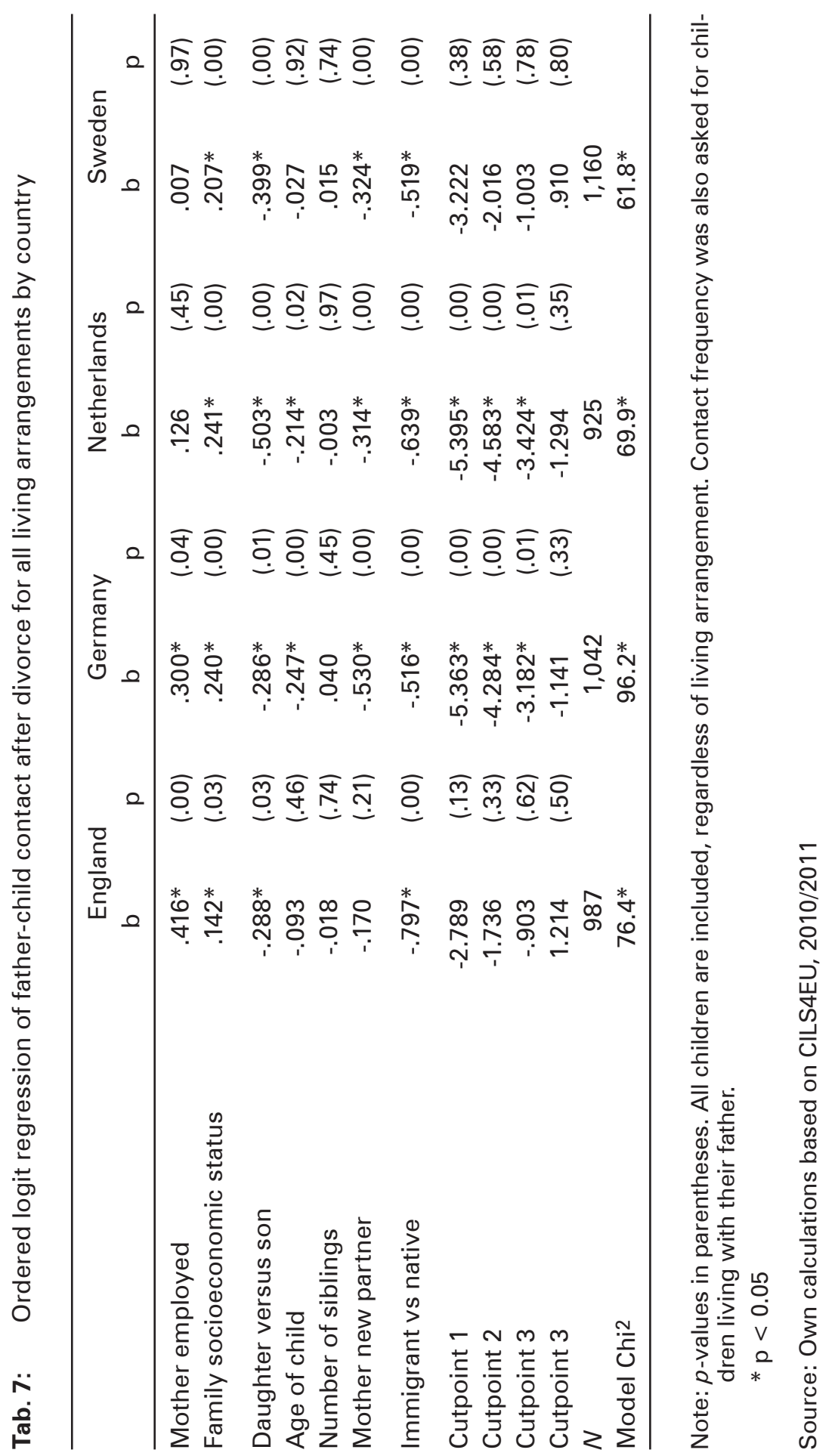


ences are consistent across countries but stepfathers have a negative effect in all countries except England. Finally, in all four countries, immigrant children less often have contact with their father than native children.

\section{Conclusion}

This paper has described the father-child relationship after divorce in four European countries, focusing on children who are about 14 years of age. Although there has been much research on these relationships, most of the research is American and little is known about the situation in Europe. Moreover, there is considerable heterogeneity in post-divorce relationships and findings about the causes of this heterogeneity are not consistent. Examples of such factors are the socioeconomic status of the family, the national context, and differences between natives and immigrants. Recent studies have made comparisons across countries, but these analyses focus on adult children who are no longer living at home. Studies of ethnic and racial differences in family functioning have been done but these have rarely looked at effects of divorce on father-child relationships.

Using nationally representative data on secondary school children in four countries, we find that there are considerable differences among divorced families. Many children have good or very good ties to their father after divorce and a large group of children either lives with the father in a co-parenting arrangement or has at least weekly contact. However, there also is a non-trivial minority of children who do not see their father at all (about one in six). Moreover, of those who do have contact, a substantial minority does not have a good relationship with the father. We suspect that this will be perceived as a problem by many fathers and children. In this sense, poor father-child relationships are one of the more problematic consequences of the divorce revolution.

To understand heterogeneity, we looked at socioeconomic factors, demographic differences, and contextual variation. High-status families generally suffer less from the adverse consequences of divorce for father-child relationships. When measured by the parent's educational level and their occupational status, socioeconomic status is positively associated with co-parenting, with frequent contact, and with the quality of the relationship. The same applies to mother's employment, which is also positively related to father-child ties, at least in two of the four countries. We interpret these findings in terms of the greater role that fathers play in children's lives before divorce in such families, more awareness of the consequences of divorce for children, and better coping strategies to deal with the practical and emotional problems after divorce.

We also found considerable demographic differences. Previous research has not consistently found gender differences but our findings are rather clear: sons more often live with the father, have more frequent contact if they do not live with him, and they also more often assess the relationship as positive. In addition, stepfathers "compete" with biological fathers in terms of contact frequency but the quality of the tie to the father is not negatively affected if the mother has a new partner. This 
suggests that the substitution effect of the stepfather is probably more practical than emotional: there is less time to visit and less need for support if the stepfather already helps out with a problem.

The context matters for understanding father-child relationships as well. Of the four countries, Sweden seems to have the most favourable post-divorce fatherchild relationships and this is largely due to more frequent co-parenting. Germany seems to have the least favourable post-divorce relationships, at least in terms of having less frequent weekly contact. These results do not support an institutionalisation perspective since England and Sweden are both high-divorce countries but ties to fathers are much stronger in Sweden than in England. The special position of Sweden, and especially the finding on co-parenting, seems more consistent with a gender-role perspective. Obviously, larger samples of countries are needed to test these ideas conclusively. One previous study of father-child contact among adult children in ten European countries found a similar pattern: stronger negative effects of divorce on father-child contact in less gender egalitarian countries (Kalmijn 2008). Our findings are consistent with this earlier study.

Contextual differences were also analysed by looking at immigrant children. Immigrant children less often live with the father after divorce and if they live with their mother, they less often have regular contact with the father. The weaker role of the immigrant father after divorce is observed for all investigated major immigrant groups. Several reasons were suggested to explain the differences. First, immigrant families tend to be more traditional in their gender roles so that fathers invest less in their children during marriage. Second, in some immigrant families, divorce is met with disapproval. This leads to a more selective group of parents who divorce (e.g. more conflict-ridden families) and can also lead to more complications after divorce (e.g. more sanctions from the community). Finally, economic considerations can play a role. Immigrant men often have a weaker economic position in society (e.g. lower income) and this makes it more difficult for them to provide a comfortable (second) home for a child after divorce. Alimony payments can also be more uncertain, and since a weak financial tie is often associated with a reduction in contact, this can be part of the explanation as well (Seltzer et al. 1989).

What do the differences tell us about these explanations? First, we observe that second-generation immigrants are more likely to see their divorced father than firstgeneration immigrants. This is in line with a cultural perspective. Second-generation immigrants are more accustomed to Western European gender roles and may become more accepting of divorce (De Graaf et al. 2011). Secondly, we found more evidence for similarities than for differences among the major immigrant groups in the four countries. Immigrants from African and Caribbean origins have less frequent contact with the non-resident father, just as immigrants from predominantly Muslim origin countries. In Muslim groups, divorce is disapproved of, but in African and Caribbean groups, divorce and non-marital childbearing are more accepted. That effects are nonetheless similar may be due to the matrifocal orientation of African and Caribbean groups (Sarkisian/Gerste/ 2004).

The children of mixed marriages seem to occupy a special position. Children of mixed marriages in which the father is foreign-born and the mother is native 
are more prone to lose contact with their father. Perhaps when mixed marriages break up, the immigrant father becomes disconnected from the mother's network because without being tied to the mother through marriage it may be difficult to bridge ethnic group boundaries. Intermarriage is often believed to connect groups and the breakup of a mixed marriage may lead to the opposite effect with unintended negative effects for one parent. New studies need to look into this issue in more detail. The possibility that the father moves back to his origin country after divorce needs to be considered as well.

We conclude with some caveats about our data. Some information is missing as the CILS4EU was a general survey and not specifically targeted to family scholars. This means that we have no information on whether the father repartnered (although we do know if the mother repartnered), we do not know the year of divorce, and we do not know where the father is living (for example, if he moved back to the origin country). The design is cross-sectional, which means that we do not know if the relationships of children and parents were already poor before the breakup. We also do not know the temporal order of some of the variables (e.g. co-parenting and mother's employment). It is clear that longitudinal data could yield more stringent tests of our hypotheses but it is rather difficult practically to collect longitudinal data with sufficient numbers of parents who divorce in between waves. There are no data where the exact same research design was used in four European countries. In this sense, the data used here are unique and provide an important first look at the problem. ${ }^{3}$ The main goal of the paper was to describe father-child relationships after divorce using nationally representative data on children. Moreover, we were able to show that there are important social differences in these relationships, related to the national context where families live, their socioeconomic status, and their immigrant status.

\section{References}

Adamsons, Kari; Johnson, Sara K. 2013: An updated and expanded meta-analysis of nonresident fathering and child well-being. In: Journal of Family Psychology 27,4: 589-599 [doi: 10.1037/a0033786].

Albertini, Marco; Garriga, Anna 2011: The effect of divorce on parent-child contacts: Evidence on two declining effect hypotheses. In: European Societies 13,2: 257-278 [doi: 10.1080/14616696.2010.483002].

Amato, Paul R. 2001: Children of divorce in the 1990s: An update of the amato and keith (1991) meta-analysis. In: Journal of Family Psychology 15,3: 355-370 [doi: 10.1037/0893-3200.15.3.355].

Aquilino, William S. 2006: Noncustodial father-child relationship from adolescence into young adulthood. In: Journal of Marriage and Family 68,4: 929-946 [doi: 10.1111/j.17413737.2006.00305.x].

3 The CILS4EU is an annual panel but there are few separations over the years. 
Arditti, Joyce A.; Keith, Timothy Z. 1993: Visitation frequency, child support payment, and the father-child relationship post-divorce. In: Journal of Marriage and the Family 55: 699-712 [doi: 10.2307/353350].

Bernardi, Fabrizio; Radl, Jonas 2014: The long-term consequences of parental divorce for children's educational attainment. In: Demographic Research 30: 1653-1680.

Bianchi, Suzanne M.; Casper, Lynne M. 2002: Continuity and change in the American family. Thousand Oaks: Sage.

Bianchi, Suzanne M. 2000: Maternal employment and time with children: Dramatic change or surprising continuity? In: Demography 37,4: 401-414 [doi: 10.2307/2648068].

Cheadle, Jacob E.; Amato, Paul R. 2011: A quantitative assessment of Lareau's qualitative conclusions about class, race, and parenting. In: Journal of Family Issues 32,5 : 679-706 [doi: 10.1177/0192513X10386305].

Cheadle, Jacob E.; Amato, Paul R.; King, Valarie 2010: Patterns of nonresident father contact. In: Demography 47,1: 205-225 [doi: 10.1353/dem.0.0084].

Cooksey, Elizabeth N.; Craig, Patricia H. 1998: Parenting from a distance: The effects of paternal characteristics on contact between nonresidential fathers and their children. In: Demography 35: 187-200 [doi: 10.2307/3004051].

Cooney, Teresa M. 1994: Young adults' relations with parents: The influence of recent parental divorce. In: Journal of Marriage and Family 56: 45-56 [doi: 10.2307/352700].

Daatland, Svein O. 2007: Marital history and intergenerational solidarity: The impact of divorce and unmarried cohabitation. In: Journal of Social Issues 63,4: 809-825 [doi: 10.1111/j.1540-4560.2007.00538.x].

De Graaf, Paul M. et al. 2011: Sociaal-culturele verschillen tussen Turken, Marokkanen en autochtonen: eerste resultaten van de Nederlandse LevensLoop Studie (NELLS). In: Bevolkingstrends 4: 61-70.

De Graaf, Paul M.; Fokkema, Tineke 2007: Contacts between divorced and non-divorced parents and their adult children in the Netherlands: An investment perspective. In: European Sociological Review 23,2: 263-277 [doi: 10.1093/esr/jcl032].

Edin, Kathryn; Kefalas, Maria 2005: Promises I can keep: Why poor women put motherhood before marriage. Berkeley: University of California Press.

Emmen, Rosanneke A. G. et al. 2013: Socioeconomic status and parenting in ethnic minority families: Testing a minority family stress model. In: Journal of Family Psychology 27,6: 896-904 [doi: 10.1037/a0034693].

Ganzeboom, Harry B.G.; De Graaf, Paul M.; Treiman, Donald J. 1992: A standard international socio-economic index of occupational status. In: Social Science Research 21,1: 1-56 [doi: 10.1016/0049-089X(92)90017-B].

Gauthier, Anne H.; De Gusti, Berenice 2012: The time allocation to children by parents in Europe. In: International Sociology 27,6: 827-845 [doi: 10.1177/0268580912443576].

Grundy, Emily; Read, Sanna 2012: Social contacts and receipt of help among older people in england: Are there benefits of having more children? In: Journals of Gerontology Series B-Psychological Sciences and Social Sciences 67,6: 742-754 [doi: 10.1093/ geronb/gbs082].

Heath, Anthony F.; Rothon, Catherine; Kilpi, Elina 2008: The second generation in Western Europe: Education, unemployment, and occupational attainment. In: Annual Review of Sociology 34: 211-235 [doi: 10.1146/annurev.soc.34.040507.134728]. 
Hofferth, Sandra L.; Forry, Nicole D.; Peters, H. Elizabeth 2010: Child support, fatherchild contact, and preteens' involvement with nonresidential fathers: Racial/ethnic differences. In: Journal of Family and Economic Issues 31,1: 14-32 [doi: 10.1007/s10834009-9172-9].

Hook, Jennifer L.; Wolfe, Christina M. 2012: New fathers? Residential fathers' time with children in four countries. In: Journal of Family Issues 33,4: 415-450 [doi: 10.1177/0192513X11425779].

Hynes, Kathryn; Dunifon, Rachel 2007: Children in no-parent households: The continuity of arrangements and the composition of households. In: Children and Youth Services Review 29,7: 912-932 [doi: 10.1016/j.childyouth.2007.02.001].

Juby, Heather et al. 2007: Nonresident fathers and children - Parents' new unions and frequency of contact. In: Journal of Family Issues 28,9: 1220-1245 [doi: 10.1177/0192513X07302103].

Juby, Heather; Le Bourdais, Céline; Marcil-Gratton, Nicole 2005: Sharing roles, sharing custody? Couples' characteristics and children's living arrangements at separation. In: Journal of Marriage and Family 67,1: 157-172 [doi: 10.1111/j.0022-2445.2005.00012.x].

Kalmijn, Matthijs 2003: Country differences in sex-role attitudes: Cultural and economic explanations. In: Arts, Wil; Hagenaars, Jacques; Halman, Loek (Eds.): The cultural diversity of European unity: Findings, explanations and reflections from the European Values Study. Leiden: Brill: 311-337.

Kalmijn, Matthijs 2007: Gender differences in the effects of divorce, widowhood and remarriage on intergenerational support: Does marriage protect fathers? In: Social Forces 85,3: 1079-1104 [doi: 10.1353/sof.2007.0043].

Kalmijn, Matthijs 2008: The effects of separation and divorce on parent-child relationships in ten European countries. In: Saraceno, Chiara (Ed.): Families, Ageing And Social Policy: Intergenerational Solidarity in European Welfare States. Cheltenham: Edward Elgar: 170-193.

Kalmijn, Matthijs 2010: Racial differences in the effects of parental divorce and separation on children: Generalizing the evidence to a European case. In: Social Science Research 39,5: 845-856 [doi: 10.1016/j.ssresearch.2010.05.002].

Kalter, Frank et al. 2012: The Children of Immigrants Longitudinal Survey in Four European Countries (CILS4EU): Motivation, aims, and design. Unpublished manuscript. Mannheim.

King, Valarie 2009: Stepfamily formation: Implications for adolescent ties to mothers, nonresident fathers, and stepfathers. In: Journal of Marriage and Family 71,4: 954-968 [doi: 10.1111/j.1741-3737.2009.00646.x].

King, Valarie; Harris, Kathleen Mullan; Heard, Holly E. 2004: Racial and ethnic diversity in nonresident father involvement. In: Journal of Marriage and Family 66: 1-21 [doi: 10.1111/j.1741-3737.2004.00001.x].

Knudsen, Knud; Wærness, Kari 2008: National context and spouses' housework in 34 countries. In: European Sociological Review 24,1: 97-113 [doi: 10.1093/esr/jcm037].

Koo, Helen; Sunchindran, C. M.; Griffith, Janet D. 1984: The effects of children on divorce and re-marriage: A multivariate analysis of life table probabilities. In: Population Studies 38,3: 451-471 [doi: 10.1080/00324728.1984.10410303].

Kraaykamp, Gerbert 2002: Cumulative Advantages and Inequality in Lifestyle: A Dutch Description of Distinction in Taste. In: The Netherlands' Journal of Social Sciences 38: 121-43. 
Lichter, Danie/ T. et al. 1992: Race and the retreat from marriage: A shortage of marriageable men? In: American Sociological Review 57,6: 781-799 [doi: 10.2307/2096123].

Lin, I-Fen 2008: Consequences of parental divorce for adult children's support of their frail parents. In: Journal of Marriage and Family 70,1: 113-128 [doi: 10.1111/j.17413737.2007.00465.x].

Mandemakers, Jornt J.; Kalmijn, Matthijs 2014: Do mother's and father's education condition the impact of parental divorce on child well-being? In: Social Science Research 44: 187-199 [doi: 10.1016/j.ssresearch.2013.12.003]

Manning, Wendy D.; Smock, Pamela J. 1999: New families and nonresident father-child visitation. In: Social Forces 78,1: 87-116 [doi: 10.1093/sf/78.1.87].

Manning, Wendy D.; Stewart, Susan D.; Smock, Pamela J. 2003: The complexity of fathers' parenting responsibilities and involvement with nonresident children. In: Journal of Family Issues 24,5: 645-667 [doi: 10.1177/0192513X03252573].

Morgan, S. Philip et al. 1993: Racial differences in household and family structure at the turn of the century. In: American Journal of Sociology 98,4: 798-828 [doi: 10.1086/230090].

Mortelmans, Dimitri et al. 2011: Scheiding in vlaanderen. Leuven: Acco.

Norris, Pippa; Inglehart, Ronald 2002: Islamic culture and democracy: Testing the 'clash of civilizations' thesis. In: Comparative Sociology 1,3: 235-263 [doi: 10.1163/156913302100418592].

Oppenheimer, Valerie Kincade 2003: Cohabiting and marriage during young men's careerdevelopment process. In: Demography 40,1: 127-149 [doi: 10.1353/dem.2003.0006].

Pels, Trees; Nijsten, Cecile 2003: Myths and realities of diversity in child rearing and parent-child relations: Non-indigeneous compared to indigeneous families in the Netherlands. In: Hagendoorn, Louk; Veenman, Justus; Vollebergh, Wilma A. M. (Eds.): Structural integration and cultural orientations in indigeneous and non-indigeneous Dutch citizens. Ashgate: Alderslot: 63-90.

Powell, Brian; Downey, Douglas B. 1997: Living in single-parent households: An investigation of the same-sex hypothesis. In: American Sociological Review 62,4: 521-539 [doi: 10.2307/2657424].

Pryor, Jan; Rodgers, Bryan 2001: Children in changing families: Life after parental separation. Malden: Oxford.

Ryan, Rebecca M.; Kalil, Ariel; Ziol-Guest, Kathleen M. 2008: Longitudinal patterns of nonresident fathers' involvement: The role of resources and relations. In: Journal of Marriage and Family 70,4: 962-977 [doi: 10.1111/j.1741-3737.2008.00539.x].

Sarkisian, Natalia; Gerstel, Naomi 2004: Kin support among blacks and whites: Race and family organization. In: American Sociological Review 69,6: 812-837 [doi: 10.1177/000312240406900604].

Sayer, Liana C.; Gauthier, Anne H.; Furstenberg, Frank F. 2004: Educational differences in parents' time with children: Cross-national variations. In: Journal of Marriage and Family 66,5: 1152-1169 [doi: 10.1111/j.0022-2445.2004.00084.x].

Seltzer, Judith A.; Bianchi, Suzanne M. 2013: Demographic change and parent-child relationships in adulthood. In: Annual Review of Sociology 39: 275-290 [doi: 10.1146/ annurev-soc-071312-145602].

Seltzer, Judith A.; Schaeffer, Nora Cate; Charng, Hong-Wen 1989: Family ties after divorce: The relationship between visiting and paying child-support. In: Journal of Marriage and Family 51,4: 1013-1031 [doi: 10.2307/353213]. 
Sobolewski, Juliana M.; Amato, Paul R. 2007: Parents' discord and divorce, parent-child relationships and subjective well-being in early adulthood: Is feeling close to two parents always better than feeling close to one? In: Social Forces 85,3: 1105-1124 [doi: 10.1353/sof.2007.0056].

Spruijt, Ed; Duindam, Vincent 2009: Joint physical custody in the Netherlands and the well-being of children. In: Journal of Divorce and Remarriage 51,1: 65-82 [doi: 10.1080/10502550903423362].

Stack, Carol B. 1974: All our kin: Strategies for survival in a black community. New York: Harper \& Row.

Stephens, Linda S. 1996: Will Johnny see daddy this week? An empirical test of three theoretical perspectives of postdivorce contact. In: Journal of Family Issues 17,4: 466494 [doi: 10.1177/019251396017004003].

Sun, Yongmin 2003: The well-being of adolescents in households with no biological parents. In: Journal of Marriage and Family 65,4: 894-909 [doi: 10.1111/j.17413737.2003.00894.x].

Swiss, Liam; Le Bourdais, Céline 2009: Father-child contact after separation the influence of living arrangements. In: Journal of Family Issues 30,5: 623-652 [doi: 10.1177/0192513X08331023].

Van Damme, Maike 2010: Beyond marriage: Women's economic independence and separation in comparative perspective. Tilburg: Ph.D. Thesis.

Van Tubergen, Frank 2004: The integration of immigrants in cross-national perspective: Origin, destination, and community effects. Amsterdam: Thesis.

Waldfogel, Jane; Han, Wen-Jui; Brooks-Gunn, Jeanne 2002: The effects of early maternal employment on child cognitive development. In: Demography 39,2: 369-392 [doi: 10.1353/dem.2002.0021].

Yaman, Ayşe et al. 2010: Parenting in an individualistic culture with a collectivistic cultural background: The case of Turkish immigrant families with toddlers in the Netherlands. In: Journal of Child and Family Studies 19,5: 617-628 [doi: 10.1007/s10826-0099346-y].

Yeung, W. Jean et al. 2001: Children's time with fathers in intact families. In: Journal of Marriage and the Family 63,1: 136-154 [doi: 10.1111/j.1741-3737.2001.00136.x].

Zander, Joep 2012: Parental alienation as an outcome of paternal discrimination. In: New Male Studies 1,2: 49-62.

Prof. Dr. Matthijs Kalmijn ( $₫)$. University of Amsterdam, Faculty of Social and Behavioural Sciences. Amsterdam, The Netherlands. E-mail: M.Kalmijn@uva.nl URL: http://www.uva.nl/en/about-the-uva/organisation/staff-members/item/m.kalmijn. html?f=Kalmijn 


\section{Comparative Population Studies}

WWW.comparativepopulationstudies.de

ISSN: 1869-8980 (Print) - 1869-8999 (Internet)

Published by / Herausgegeben von

Prof. Dr. Norbert F. Schneider

Federal Institute for Population Research

D-65180 Wiesbaden / Germany

\section{Managing Editor /}

Verantwortlicher Redakteur

Frank Swiaczny

\section{Assistant Managing Editor /}

\section{Stellvertretende Redakteurin}

Katrin Schiefer

\section{Copy Editor (German) /}

Lektorat (deutsch)

Dr. Evelyn Grünheid

\section{Layout / Satz}

Beatriz Feiler-Fuchs

E-mail:cpos@bib.bund.de

\section{Scientific Advisory Board /}

Wissenschaftlicher Beirat

Paul Gans (Mannheim)

Johannes Huinink (Bremen)

Michaela Kreyenfeld (Rostock)

Marc Luy (Wien)

Clara H. Mulder (Groningen)

Notburga Ott (Bochum)

Peter Preisendörfer (Mainz)

Zsolt Spéder (Budapest)
Board of Reviewers / Gutachterbeirat Martin Abraham (Erlangen)

Laura Bernardi (Lausanne)

Hansjörg Bucher (Bonn)

Claudia Diehl (Konstanz)

Andreas Diekmann (Zürich)

Gabriele Doblhammer-Reiter (Rostock)

Jürgen Dorbritz (Wiesbaden)

Anette Eva Fasang (Berlin)

E.-Jürgen Flöthmann (Bielefeld)

Alexia Fürnkranz-Prskawetz (Wien)

Beat Fux (Salzburg)

Joshua Goldstein (Berkeley)

Karsten Hank (Köln)

Sonja Haug (Regensburg)

Hill Kulu (Liverpool)

Aart C. Liefbroer (Den Haag)

Kurt Lüscher (Konstanz)

Emma Lundholm (Umeå)

Nadja Milewski (Rostock)

Dimiter Philipov (Wien)

Roland Rau (Rostock)

Tomáš Sobotka (Wien)

Jeroen Spijker (Barcelona)

Olivier Thévenon (Paris)

Helga de Valk (Brussel)

Heike Trappe (Rostock)

Michael Wagner (Köln) 